\title{
Strategy to Increase Selling Price of Toraja Arabica Coffee Farmers as High Value National Commodities in International Markets
}

\section{Yopie Brian Suryadhy Panggabean', Yunus Musa², Rahim Darma ${ }^{3}$, Didi Rukmana4, Rinaldi Sjahril5, Mahyuddin6}

${ }^{1}$ Agribusiness Study Program, Postgraduate School of Hasanuddin University, Makassar, Indonesia

${ }^{2}$ Lecturer of Agribusiness Program, Postgraduate School, Hasanuddin University, Makassar, Indonesia

Correspondence Author: Yopie Brian Suryadhy Panggabean, ${ }^{1}$ Agribusiness Study Program, Postgraduate School of Hasanuddin University, Makassar, Indonesia

Email: panggabeanbrian@gmail.com

Received date: 28 August 2019, Accepted date: 15 November 2019, Online date: 26 November 2019

Copyright: (C) 2019 Yopie Brian Suryadhy Panggabean et al., This is an open-access article distributed under the terms of the Creative Commons Attribution License, which permits unrestricted use, distribution, and reproduction in any medium, provided the original author and source are credited.

\begin{abstract}
Arabica coffee owned by Toraja especially North Toraja is very distinctive with the aroma and flavor produced so that it becomes its own attraction in the hearts of coffee enthusiasts everywhere. But behind the taste and aroma that is very unique there are many problems faced by Arabica coffee farmers in Toraja in particular. This study aims to analyze the potential of North Toraja Arabica coffee agribusiness, which is then followed by studying the benefits that can be done of create an appropriate strategy to improve quality in Arabica coffee agribusiness competition. Data taken using observations and direct interviews in the form of a questionnaire to farmers that includes how much can be produced each harvest season, and the price received each sell the harvest to collectors, companies, and several parties who participated in this research. Primary data used in this study are quantitative and qualitative data. The results of this study indicate that the Arabica coffee owned by Toraja has the potential, farmers as producers have a very big role in improving the performance of Arabica coffee development programs. However, observations show that policies in developing human resources in rural areas, especially in terms of farmers' quality and skills, are relatively not working as expected. To reduce the level of dependence of farmers to traders, it is necessary to strive for financial institutions that are able to provide capital needs to farmers in a fast time without complicated procedures. Therefore, farmers have alternatives to choose marketing channels that can provide better prices.
\end{abstract}

Keywords: North Toraja, Potential, Arabica Coffee, Farmer Income Strategy

\section{INTRODUCTION}

One of the sub-sectors that is expected to make an essential contribution to agricultural development is a plantation. The plantation is a subsector that contributes to the national economy through employment, national income, foreign exchange and tax income [1]. It was noted that in 2012 the value of coffee exports which reached 1.5 billion USD continued to decline until 2014, then strengthened again in 2015, and again declined in 2016 which only reached 1.4 billion USD. The decline in exports was caused by the decrease in domestic coffee production which only reached 639,305 tons in 2016 or decreased $0.02 \%$ from the previous year, which reached 639,412 [2].

The development of Indonesia's coffee export volume in the period 1980-2016 fluctuated with an increasing trend on average of $3.80 \%$ per year, ie Indonesia's coffee exports in 1980 amounted to 238.68 thousand tons with an export value of 656 million USD and in 2016 the volume of coffee exports to 414.65 thousand tons or the US $\$ 1,008.55$ million. The growth in volume and value of coffee exports in 5 years (from 2012 to 2016) in volume has recorded a slowdown in the growth of $1.04 \%$ per year with an export value that has decreased by $4.52 \%$ per year or an export value of $1,133.84$ USD million. The highest drop in the volume of Indonesian coffee exports occurred in 2014 of $27.94 \%$ or reaching 384.82 thousand tons, with a drop in the value of Indonesian coffee exports by $11.47 \%$ or an export value of US $\$ 1,039.34$ million. It was thought that the decline in coffee exports in the year had been triggered by a $5.40 \%$ decline in coffee production in the same year, particularly in the decline in coffee production on community plantations, which fell by $5,03 \%$ or that the production reached 612.88 thousand tons of rice coffee [3]. 
North Toraja Regency is one of the coffee-producing areas in South Sulawesi. Arabica coffee and Robusta coffee are the results of the dominant plantation crops and are much in demand by outside communities and communities in North Toraja Regency itself. This is caused by the production of coffee which is a superior product in North Toraja Regency, besides that cocoa is also one of the other superior products available. Coffee production yield reached 3,033.67 tons which were harvested from an area of 9,924.75 ha. While cocoa production reached 776.20 tons which were harvested from an area of 1,542.00 ha. During 20132017, smallholder plantations in South Sulawesi Province averaged 12.50\% of Indonesia's Arabica coffee, equivalent to 20.10 thousand tons per year [4].

Each farmer has a business capacity that depends on land, capital, livestock ownership, and management systems that produce different incomes. Arabica coffee demand higher than supply is an opportunity for the development of the Arabica coffee business [5]. Just as in the beef cattle business, which was established with the primary goal of producing agricultural products to meet community demand for animal protein needs and aims to generate profits [5]. The purpose of this study is to analyze the potential of Toraja Arabica coffee agribusiness, including prices sold by farmers to buyers. This is then followed by providing appropriate strategies to improve the quality of agribusiness competition in Arabica coffee commodities.

\section{RESEARCH METHODS}

Data collection is done through observation and direct interviews conducted by Simple Random Sampling. The determination of farmers' respondents is based on random sampling on the number of farmers working in Arabica coffee plants in the village of Sapan, in the Buntu Pepasan district and considering that several officials took the determination of the interviewees as key informants in the field of plantation production and horticulture, Northern Toraja District Agriculture Office, fellow Arabica coffee growers from the Buntu Pepasan district, collectors and traders.

Next is the random selection of respondents of farmers each taken $30 \%$ from all Arabica coffee farmers who have become representatives of all Arabica coffee farmers in the Papasan village area. States that for the research that will use statistical data the sample size smaller than $30 \%$ may already represent the population. This sampling method is performed by probabilistic sampling in which the sampling is carried out giving equal opportunity to each member of the population to be elected as a sample [6]. The technique used is a simple random sampling. This research also uses SWOT analysis to see strengths, weaknesses, opportunities, threats. SWOT matrix preparation is based on internal and external strategic factors that are determined based on conditions in the field when the research and data that have been collected both primary and secondary data [7]. To create a strategy to increase the selling price of Arabica coffee in North Toraja, using the AHP analysis method, to obtain the required strategy.

\section{RESULTS AND DISCUSSION}

From the results of research that has been done that the price received by farmers is still not in accordance with what is expected by farmers, one of which is, because of the lengthy process of selling their produce, which starts from selling to traders. In 2018, the price sold by farmers to collectors in the range of Rp. 18,000 / liter alone is what makes farmers tend to make farmers less serious and have no enthusiasm in conducting cultivation, and also the lack of attention from the government to farmers to provide solutions how ways to increase their agricultural output can be more optimal and have the best quality so that it can achieve the required production targets, the lack of management of coffee cultivation that is not following the recommendations, which are some obstacles to productivity and economic income of coffee farmers in North Toraja and most farmers are still many use old plants and do not rejuvenate or plant using new seeds because they require a long process of production, so that the coffee farms that farmers use now have no optimal productivity.

Priorities with respect to:

Goal: Strategi Pengembangan Pendapatan Agribisnis Kopi Arabika di Toraja Utara

$>$ Manajemen Pertanian

Meningkatkan pendidikan petani di bidang ilmu pertanian Meningkatkan fokus pemerintah terhadap kebutuhan petani kopi arabika

Menguatkan kerjasama antar petani, pesagang, pengumpul maupun perusahaan terlibat

Mengembangkan wilayah pemasaran bagi petani

Meningkatkan efektifitas penggunaan pupuk dan pestisida alami

Memperbanyak wilayah khusus untuk kopi arabika khas Traja Utara

Menguatkan kebijakan pemerintah dalam memberikan harga satuan tetap untuk kopi arabika

Meningkatkan produktifitas kopi arabika Toraja Utara

Mengembangkan teknologi produksi dan pengolahan kopi arabika

Membuat aplikasi pemasaran berdasarkan kualitas untuk komoditi kopi arabika

Menstabilkan harga di tingkat petani, pedagang, pengumpul dan perusahaan

Inconsistency $=0,04$

with 0 missing judgments.

Data 1. The overall combination of agricultural management criteria 
Meningkatkan produktifitas kopi arabika Toraja Utara

Meningkatkan efektifitas penggunaan pupuk dan pestisida alami

Mengembangkan wilayah pemasaran bagi petani

Memperbanyak wilayah khusus untuk kopi arabika khas Traja Utara

Menstabilkan harga di tingkat petani, pedagang, pengumpul dan perusahaan

Membuat aplikasi pemasaran berdasarkan kualitas untuk komoditi kopi arabika

Menguatkan kerjasama antar petani, pesagang, pengumpul maupun perusahaan terlibat

Mengembangkan teknologi produksi dan pengolahan kopi arabika

Meningkatkan pendidikan petani di bidang ilmu pertanian

Menguatkan kebijakan pemerintah dalam memberikan harga satuan tetap untuk kopi arabika

Meningkatkan fokus pemerintah terhadap kebutuhan petani kopi arabika

Inconsistency $=0,04$

with 0 missing judgments.

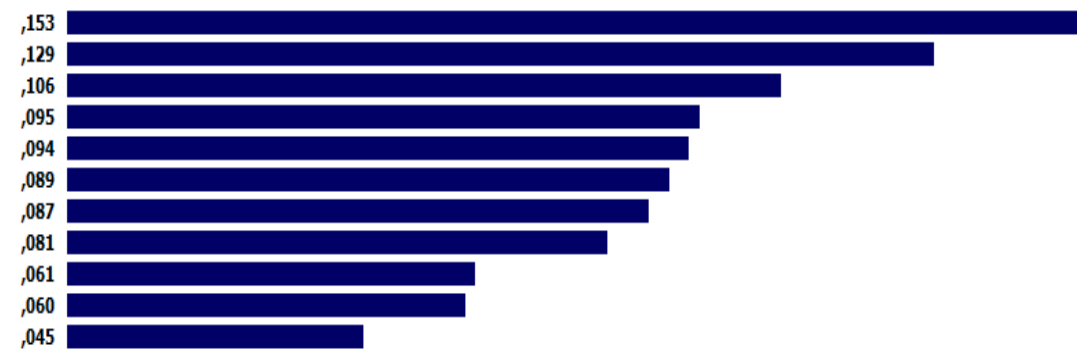

Data 2. The overall combination of production and marketing criteria

\begin{tabular}{|c|c|c|c|c|c|c|}
\hline \multirow[b]{2}{*}{ ALTERNATIVE } & \multicolumn{4}{|c|}{ CRITERIA } & \multirow{2}{*}{ Average } & \multirow{2}{*}{ Priority } \\
\hline & 1 & 2 & 3 & 4 & & \\
\hline a. Increasing North Toraja Arabica Coffee Productivity & 0,081 & 0,153 & 0,074 & 0,037 & 0,08625 & 9 \\
\hline $\begin{array}{l}\text { b. Increase the effectiveness of the use of natural fertilizers and } \\
\text { pesticides }\end{array}$ & 0,092 & 0,129 & 0,096 & 0,052 & 0,09225 & 3 \\
\hline c. Develop marketing areas for farmers & 0,094 & 0,106 & 0,102 & 0,063 & 0,09125 & 4 \\
\hline $\begin{array}{l}\text { d. Increase government focus on the needs of Arabica coffee } \\
\text { farmers }\end{array}$ & 0,129 & 0,045 & 0,089 & 0,072 & 0,08375 & 11 \\
\hline $\begin{array}{l}\text { e. Strengthening government policy in providing fixed unit prices } \\
\text { for Arabica coffee }\end{array}$ & 0,083 & 0,06 & 0,147 & 0,08 & 0,0925 & 2 \\
\hline $\begin{array}{l}\text { f. Strengthen cooperation between farmers, traders and companies } \\
\text { involved }\end{array}$ & 0,098 & 0,087 & 0,058 & 0,118 & 0,09025 & 6 \\
\hline $\begin{array}{l}\text { g. Developing Arabica coffee production and processing } \\
\text { technology. }\end{array}$ & 0,071 & 0,081 & 0,067 & 0,122 & 0,08525 & 10 \\
\hline h. Improving farmer education in the field of agricultural science. & 0,144 & 0,061 & 0,083 & 0,07 & 0,0895 & 8 \\
\hline $\begin{array}{l}\text { i. Increasing the area specifically for Arabica coffee typical of } \\
\text { North Toraja }\end{array}$ & 0,09 & 0,095 & 0,067 & 0,108 & 0,09 & 7 \\
\hline j. Stabilizing prices at the level of farmers, traders and companies & 0,057 & 0,094 & 0,164 & 0,114 & 0,10725 & 1 \\
\hline $\begin{array}{l}\text { k. Create applications for marketing based on quality for Arabica } \\
\text { coffee commodities }\end{array}$ & 0,061 & 0,089 & 0,051 & 0,164 & 0,09125 & 5 \\
\hline INCONSISTENCE RATIO & 0,04 & 0,04 & 0,04 & 0,04 & 0,04 & \\
\hline
\end{tabular}


with 0 missing judgments.

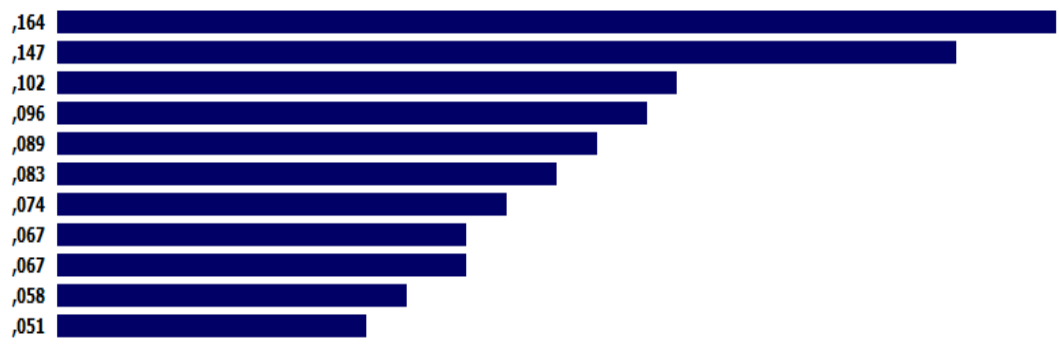

Data 3. The overall combination of fixed commodity pricing criteria Priorities with respect to:

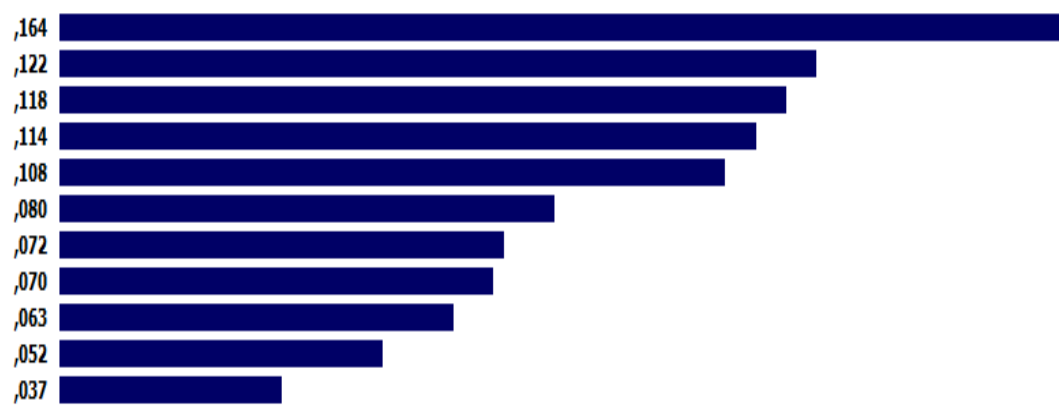

Data 4. The overall combination of technology application criteria

Table of analysis results using the AHP method Source: Primary Data Analysis, 2019

From the results of research that has been done, it was found that the dominance of farmers in the northern Toraja area, especially in the village of Rante Uma still uses natural fertilizers, this is a very good opportunity because farmers are still using traditional methods, but what needs to be increased is how the role of government especially extension workers for how to provide education to farmers so that farmers can increase their productivity. The factor which has become an obstacle for farmers in Rante Uma is that the active coffee farms in the community have an inappropriate slope topography/slope.

One solution to increase the selling price of farmers is to increase agricultural coffee by processing coffee plantations, so that the Arabica coffee produced can increase and also improve the quality of products obtained in Arabica coffee products produce good, so it can affect, with the amount of productivity that will also be increased, so that Arabica coffee farmers in North Toraja also have a value of selling prices that are in accordance with the quality in accordance with the market needs of two domestic consumers producing the equivalent and buyers from abroad. The potential of livestock as a provider of organic fertilizer is maximized through the processing of faeces and urine as compos [8].

The need for a state pricing policy is right for farmers to make farmers excited, there is also a need for training for farmers so that farmers cultivate their coffee plantations. To improve the quality of the workforce, aspects of formal and informal education must be improved. If farmers want more yield growth, a skilled and qualified workforce is needed [9]. What is needed now is the development of marketing areas and the government must also focus on the needs of farmers who will affect the quality of the Arabica coffee they produce so that farmers' income can increase and the sustainability of Arabica agricultural coffee as an Arabica coffee center in South Sulawesi can be continued.

The strategy to improve marketing for farmers is to adjust the time based on technology or the Internet, such as creating applications where farmers can market their products to sell easily without having to go through a long process and not just depend on selling to traders to make money quickly. With the application to market these coffee products, farmers are expected to sell their coffee production with better quality. This could also be one of the strategies to increase the enthusiasm of farmers towards agriculture, which began to diminish because they no longer have a future that is still farming, have little profit, but change the way of thinking about agriculture in the form of sustainable economic support to agriculture in Indonesia. 
There is also a need for technological developments in the field of harvesting and post-harvesting for Arabica coffee farming, such as Arabica coffee processing machines at affordable prices to train farmers to become independent entrepreneurs and make their own products without making the profit they get even more compared to selling coffee beans only. To increase agricultural productivity better or modern technologies such as their use are needed high-quality seeds [10].

\section{CONCLUSION}

With the improvement of the management of the Arabica coffee farm, which is based on the care of the coffee plantations and the rejuvenation of the crops so that the farmers can increase their productivity and quality, and with the development of the technology, the farmers can process their agricultural products to generate income to increase and sell their products using technologies such as applications to market the products manufactured by farmers.

\section{REFERENCE}

[1] Syamsinar, Amal, Sitti Nurani Sirajuddin. 2015. Analysis of Factors Associated with the Size of Receipt Reinvestment Cocoa Farming. American-Eurasian Journal Of Sustainable Agriculture. ISSN: 1995-0748, EISSN: $1998-1074$ 2015, volume (9), issue (4):pages (8-14)

[2]. Pusat Data dan Sistem Sistem Pertanian.2016. Outlook Komoditi kopi. Kementerian Pertanian. Jakarta.

[3]. International Coffee Organization. http://www.ico.org/profilese.asp?section= Statistics accessed on 18 Juni 2019.

[4] Pemerintah Daerah Kabupaten Toraja Utara. 2017. Jenis, luas dan total produksi tanaman perkebunan di Toraja Utara. www.toraja-utarakb.go.id/index.php/potensi-daerah/perkebunan.accessed on 2 Juli 2019.

[5] Sitti Nurani Sirajuddin, Siti Nurlaelah, Amidah Amrawaty, Amrullah T, St. Rohani, Ikrar Moh. Saleh. 2017. Relationship Between Farmers Characteristic and Income from Beef Cattle with The Traditional Profit-Sharing. American-Eurasian Journal Of Sustainable Agriculture. ISSN: 1995-0748, EISSN: 1998-1074 2017, volume (11),issue (5):pages (29-34)

[6] I Made Wirartha. 2006. Socio-Economic Assessment Methodology. Yogyakarta: C.V Andi Offset.

[7] Rangkuti. F. 2015. Analisis SWOT Teknik Membedah Kasus Bisnis. PT. Gramedia Pustaka Utama. Jakarta.

[8] Syamsul Bahri, Asmuddin Natsir, Nurani Sirajuddin, Syamsuddin Hasan.2018. Integrated Agricultural System on Crops: Intercropping of Corn - Peanut and Beef Cattle Fattening. International Journal of Current Research in Biosciences and Plant Biology. Volume (5), ISSN: 2349-8080, pages (24-29).

[9] Irene Kartika Eka Wijayanti, Jamhari, Dwidjono Hadi Darwanto, Any Suryantini. 2019. Production Risk and Factors Influencing Strawberry Farming in Purbalingga Regency, Indonesia. American-Eurasian Journal Of Sustainable Agriculture. ISSN : 1995-0748, EISSN: 1998-1074 2019, Volume (13), Issue (1) : Pages (9-17).

[10] Nurhapsa, Nunung Kusnadi, Muhammad Firdaus and Sitti Nurani Sirajuddin. 2014. Factors Affecting Farmer's Productivity New Potato Yield Varieties. American-Eurasian Journal of Sustainable Agriculture. ISSN : 1995-0748, Volume (8), Issue (2) : pages 52-57 